\title{
PELATIHAN PENYELESAIAN SOAL MATEMATIKA BERBASIS MATRIKS DI YAYASAN CAHAYA ISLAM MUTIARA IMANI PAMULANG TANGERANG SELATAN
}

\author{
Aden ${ }^{\text {1), Tabah Heri Setiawan }}{ }^{2)}$, Ilmadi ${ }^{3)}$, Yulianti Rusdiana ${ }^{4)}$, Nina Valentika ${ }^{5}$ ) \\ 1,2,3,4,5 Program Studi Matematika, Fakultas Matematika dan Ilmu Pengetahuan Alam, Universitas \\ Pamulang
}

\begin{abstract}
Abstrak
Metode matriks merupakan metode yang dikembankan oleh tim pengabdian kepada masyarakat untuk penyelesaian persoalan matematika. Tujuan dari pengabdian kepada masyarakat yaitu mengetahui apakah terjadi peningkatan kemampuan dalam menyelesaikan persoalan matematika setelah proses pelatihan atau tidak, mengetahui dorongan apakah yang diajukan kepada siswa untuk menimbulkan kesadaran dalam belajar. Metode yang digunakan menggunakan Uji t Dua Sampel atau uji t Test paired. Hasil yang diperoleh terjadi peningkatan kemampuan dalam menyelesaikan persoalan matematika setelah diberikan penyuluhan, serta hal yang perlu di dorong kepada siswa yaitu mempunyai soal-soal yang variatif yang dapat diperoleh dari web maupun buku.
\end{abstract}

Kata Kunci: Matriks, t Test

\begin{abstract}
The matrix method is a method developed by the community service team for solving mathematical problems. The aims of community service is to find out whether there is an increase in the ability to solve math problems after the training process or not, to find out what encouragement is given to students to raise awareness in learning. The method used is the two-sample t test or paired t test. The results obtained were an increase in the ability to solve math problems after being given counseling, as well as things that need to be encouraged to students, namely having a variety of questions that can be obtained from the web or books.
\end{abstract}

Keywords: Matrix, $t$ Test

Correspondence author: Aden, dosen00527@unpam.ac.id, South Tangerang, Indonesia 
Pelatihan Penyelesaian Soal Matematika Berbasis Matriks Di Yayasan Cahaya Islam Mutiara Imani

\section{PENDAHULUAN}

\subsection{Analisis Situasi}

Ujian nasional merupakan hal yang sangat serius diperbincangkan oleh warga negara Indonesia. Karena dengan Ujian Nasional ini nasib di ujung penyelesaian sekolah aik SD, SMP maupun SMA. Bagaimana tidak dengan Ujian Nasional nasib anak-anak sangat ditentukan sekali untuk lulus atau tidak lulusnya anak. Persoalan keluarga yaitu ketika melihat anaknya akan menghadapi ujian nasonal (UN) dengan berbagai bentuk mata pelajaran. Salah satunya adalah mata pelajaran Matematika. Matematika memang mata pelajaran yang menyeramkan. Untuk merubah emage itu maka perlu adanya pelatihan-pelatihan penyelesaian persoalan matematika dengan cara yang cepat, tepat dan menyenangkan.

Banyaknya rumus yang harus dihafalkan sehingga memerlukan ingatan yang sangat baik teelebih memerlukan latihan-latihan yang sering dilakukan. Memperdalam dengan mengikuti privat dan bimbingan belajar menjadi alternatif untuk menyelesaikan problematika kegundahan orang tua terhadap anaknya. Bahakan banyak sekolah yang mengadakan tambahan pembelajaran di luar jadwal pembelajaran. Pelaksanaannya ada yang pagi dan ada juga yang dilaksanakan pada sore hari.

Keseriusan dalam menghadapi ujian nasional menjadikan anak-anak didik yang akan menghadapi ujian atersebut membuat agenda-agenda pelatihan penyelesaian soal. Kami dari Universitas Pamulang Program Studi matematika hadir untuk membantu penyelesain persoalan ini dengan menggunakan metode matriks denan kecepatan dan ketepatan untuk menjawab persoalan tertentu pada soal matematika. Sehingga diharapkan tidak memerlukan banyak penghafalan perumusan untuk menyelesaikan persoalan. Yang pada akhirnya anak-anak didik akan merasa senang untuk menyelesaikan persoalan matematika.

Universitas Pamulang (UNPAM) merupakan kampus yang berdiri di bawah naungan Yayasan Sasmita Jaya yang beralamat di Jl. Surya Kencana No. 1 pamulang dengan mengemban visi "Menjadi Universitas Peringkat 40 besar pada tingkat Nasional yang dilandasi oleh nilai humanis dan religius pada tahun 2024". UNPAM dalam lingkup perguruan tinggi ada di dalam wilayah lingkungan LLDIKTI wilayah IV.

Program Studi Matematika Fakultas MIPA Universitas Pamulang membuka diri untuk melakukan berbagai kerjasama dengan berbagai pihak dalam rangka pengembangan ilmu, institusi, teknologi dan seni dalam rangka pelaksanaan Tri Dharma Perguruan Tinggi yakni Pendidikan, Penelitian dan Pengabdian. UNPAM sudah mempunyai jaringan dengan berbagai lembaga lain yakni pemerintah pusat, pemerintah propinsi, pemerintah kabupaten, dunia usaha, swasta maupun dengan masyarakat.

Melihat lokasi kampus yang tidak jauh dengan lokasi Yayasan Cahaya Islam Mutiara Imani, maka sudah menjadi kewajiban bagi perguruan tinggi untuk ikut serta membantu berbagai persoalan yang dihadapi oleh anak-anak didik serta pengurus dalam menangani persoalan pemecahan permasalahan dalam matematika. Sudah selayaknya kehadiran perguruan tinggi agar dapat benar-benar dirasakan manfaatnya oleh masyarakat baik yang dekat maupun yang jauh. 
Pengabdian ini dilaksanakan selain berguna untuk pengurus, anak-anak didik di Yayasan CIMI juga dapat dijadikan sebagai pembelajaran mahasiswa dan alumni dalam memecahkan persoalan matematika. Selain itu juga dapat dijadikan sebagai model atau metode pembelajaran yang dapat diterapkan di tempat mahasiswa atau alumni suatu saat bekerja. Sehingga lebih mudah diterima penjelasannya ketika memecahkan persoalan yang berhubungan dengan matematika.

Sesuai dengan hasil pengabdian terlebih dahulu yaitu menunjukkan hasil penelitian menunjukkan bahwa ada peningkatan kemampuan menyelesaikan soal UN bagi guru SMP setelah mengikuti pelatihan tentang pengembangan soal UN (Khairudin, K., \& Niniwati, N., 2020). Program pengabdian ini disusun berdasarkan hasil survey pendahuluan oleh TIM PKM ke lokasi Yayasan Cahaya Islam Mutiara Imani serta wawancara kepada pengurus. Sehingga kami dari Tim Program Pengabdian Masyarakat (PKM) Universitas Pamulang (UNPAM) yang berjumlah 4 dosen terpanggil untuk ikut serta membantu menyelesaikan persoalan pembelajaran matematika yang dihadapi oleh anak-anak didik Yayasan Caha Islam Mutiara Imani dengan judul PKM: "Pelatihan Penyelesaian Soal Matematika Berbasis Matriks di Yayasan Cahaya Islam Mutiara Imani Pamulang Tangerang Selatan”.

\subsection{Rumusan Masalah}

Rumusan masalah pada pengabdian ini yaitu:

1). Apakah terjadi peningkatan kemampuan dalam menyelesaikan persoalan matematika setelah proses pelatihan?

2). Apakah yang harus didorong kepada siswa untuk mendorong kesadaran dalam belajar?

\subsection{Tujuan Pengabdian kepada Masyarakat}

Tujuan pengabdian kepada masyarakat yang dilaksanakan di Yayasan CIMI yaitu:

1). Mengetahui apakah terjadi peningkatan kemampuan dalam menyelesaikan persoalan matematika setelah proses pelatihan atau tidak.

2). Mengetahui dorongan apakah yang diajukan kepada siswa untuk menimbulkan kesadaran dalam belajar.

\subsection{Metode Penyelesaian Matriks}

Metode matriks guna penyelesaian soal matematika merupakan metode yang dikembangkan untuk mempermusdah dalam penyelesaian persoalan sehingga tidak memerlukan pemahaman yang terlalu rumit dikarenakan fokus kepada persoalan ujian akhir baik SD maupun SMP. Penyelesaian dalam memecahkan persoalan matematika mengikutsertakan seluruh tutor dalam pelatihan, sehingga akan menghasilkan output yang baik. Selain itu juga seorang tutor harus dapat mengidentifikasi kemajuan, ketercapaian, kesalahan dan kesimpulan dari proses belajar seorang murid. (Arikunto: 2012) 
Pelatihan Penyelesaian Soal Matematika Berbasis Matriks Di Yayasan Cahaya Islam Mutiara Imani

\section{METODE PELAKSANAAN}

\subsection{Kerangka Pemecahan Masalah}

Hal mendasar kerangkan pemecahan masalah yang ditawarkan melalui kegiatan penyuluhan dan pelatihan kepada pengurus Yayasan Cahaya Islam Mutiara Imani serta anak-anak didik yang berada dalam naungannya dengan bentuk PKM "Pelatihan Penyelesaian Soal Matematika Berbasis Matriks di Yayasan Cahaya Islam Mutiara Imani Pamulang Tangerang Selatan". Untuk lebih jelasnya dapat dilihat dalam skema di bawah ini:

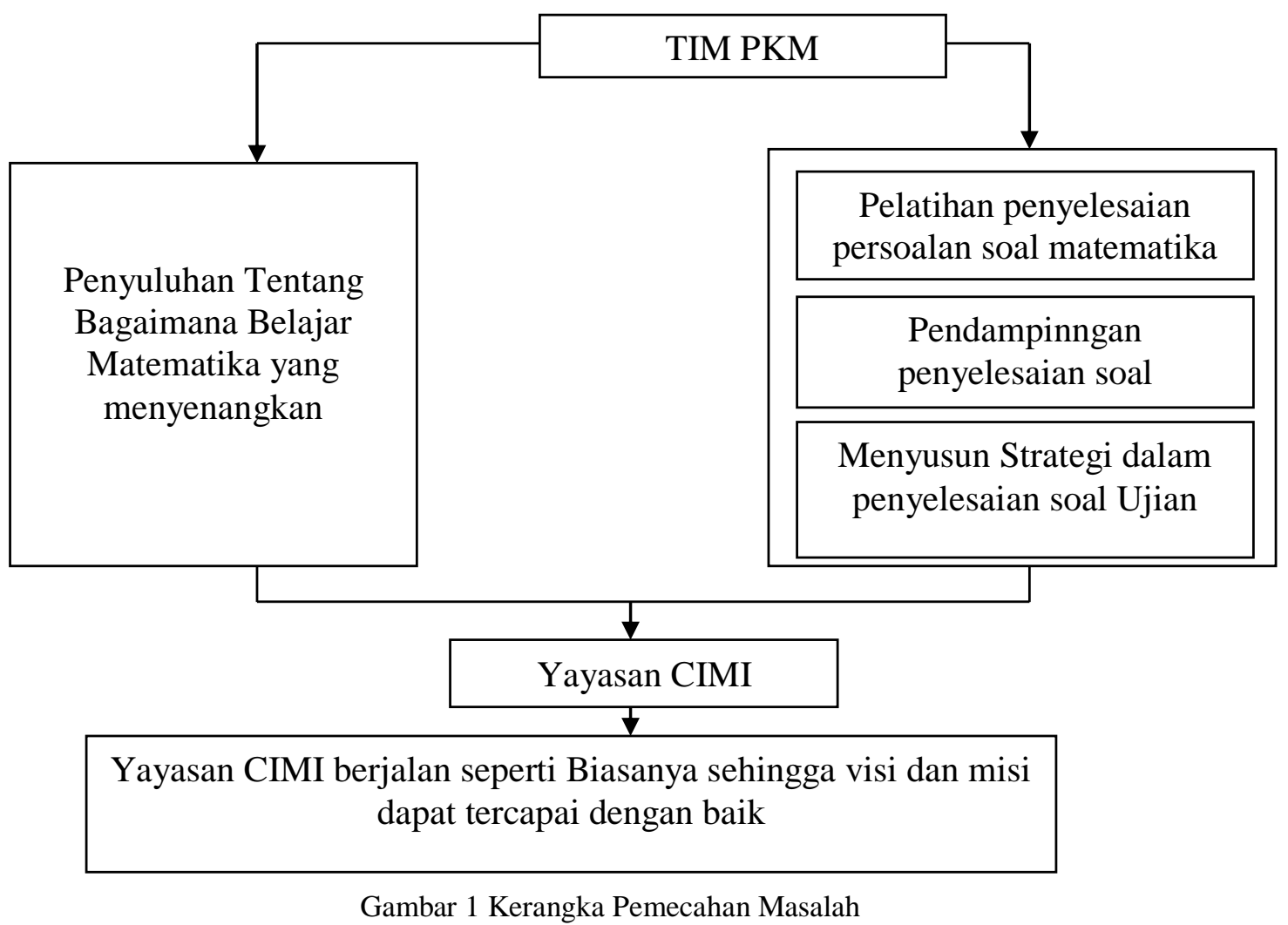

\subsection{Realisasi Pemecahan Masalah} yaitu:

Realisasi pemecahan masalah PKm yang dilaksanakan melalui tiga tahapan

1). Tahapan pertama yaitu tahapan penyelesaian persoalan matematika dengan tingkatan SD dan SMP dengan dilaksanakan terpisah dengan Pendamping berbeda dengan pelaksanaan dibuat serileks mungkin sehinga mereka mengerjakan dengan maksimal. Menilai hasil pekerjaan dari peserta Pkm dengan dijadikan nilai awal sebelum tritment atau $\mathrm{X}_{1}$.

2). Tahapan kedua yaitu pembahasan soal-soal matematika dengan metode yang unik diberikan oleh Pendamping yang diberikan oleh Dosen Universitas Pamulang.

3). Tahapan ketiga yaitu mengerjakan kembali soal-soal yang sesuai dengan soal awal untuk dijadikan nilai sesudah diberikan tritment yaitu $\mathrm{X}_{2}$. Kemudian 
dilanjutkan untuk membuat analisa untuk melihat apakah pengabdian kepada masyarakat yang telah dilaksanakan sesuai dengan apa yang direncanakan atau tidak.

Setelah tiga tahap di atas terlaksana tahap selanjutnya yaitu Evaluasi kegiatan dilakukan setelah kegiatan penyuluhan dan pelatihan kepada Yayasan CIMI yaitu dengan cara mengisi instrument yang disiapkan oleh TIM PKM terkait bagaimanakah tanggapan Yayasan CIMI terhadap kegiatan PKM yang dilakukan oleh Tim Dosen Matematika Universitas Pamulang.

\subsection{Khalayak Sasaran}

Sasaran program pengabdian masyarakat yang akan di tuju adalah Yayasan CIMI yang beralamatkan di Pondok Benda Indah Kel. Pondok Benda Kec. Pamulang, Tangerang Selatan sejumlah 35 Orang. Jumlah 35 Orang itu terdiri dari:

$$
\begin{array}{ll}
5 \text { Orang } & \text { : Guru dan Yayasan CIMI } \\
30 \text { Orang } & \text { : Anak didik Yayasan CIMI }
\end{array}
$$

\subsection{Tempat dan Waktu}

Tempat pelaksanaan PKM di Aula Yayasan Cahaya Islam Mutiara Imani (CIMI). Waktu pelaksanaan pada tanggal 23 Desember 2018, 6 \&13 Januari 2019.

\subsection{Metode Kegiatan}

Metode yang akan digunakan dalam pengabdian masyarakat ini adalah melalui kegiatan:

1). Penyuluhan tentang penyelesaian persoalan soal-soal.

2). Pelatihan penyelesaian soal matematika

\section{HASIL DAN PEMBAHASAN}

\subsection{Hasil}

Data hasil penilaian tahap awal sebagai nilai awal yaitu menyelesaikan soal pada hari pertama $\mathrm{Pkm}$ dijadikan $\mathrm{X}_{1}$ dan nilai akhir yang diperoleh pada hari ketiga setelah dilaksanakan penyuluhan dengan metode matriks dijadikan data $\mathrm{X}_{2}$. Data tersebut sebagai berikut.

Tabel 1 Data Nilai Awal dan Nilai Akhir

\begin{tabular}{|c|c|c|}
\hline $\begin{array}{c}\text { No } \\
\text { Peserta }\end{array}$ & Nilai Awal $\left(\mathbf{X}_{\mathbf{1}}\right)$ & Nilai Akhir $\left(\mathbf{X}_{\mathbf{2}}\right)$ \\
\hline 1 & 60 & 65 \\
\hline 2 & 60 & 55 \\
\hline 3 & 65 & 75 \\
\hline 4 & 40 & 54 \\
\hline
\end{tabular}


Pelatihan Penyelesaian Soal Matematika Berbasis Matriks Di Yayasan Cahaya Islam Mutiara Imani

\begin{tabular}{|c|c|c|}
\hline $\begin{array}{c}\text { No } \\
\text { Peserta }\end{array}$ & Nilai Awal $\left(\mathbf{X}_{\mathbf{1}}\right)$ & Nilai Akhir $\left(\mathbf{X}_{\mathbf{2}}\right)$ \\
\hline 5 & 46 & 65 \\
\hline 6 & 30 & 45 \\
\hline 7 & 45 & 40 \\
\hline 8 & 70 & 67 \\
\hline 9 & 78 & 82 \\
\hline 10 & 66 & 70 \\
\hline 11 & 45 & 40 \\
\hline 12 & 40 & 54 \\
\hline 13 & 40 & 45 \\
\hline 14 & 68 & 65 \\
\hline 15 & 70 & 65 \\
\hline 16 & 50 & 70 \\
\hline 17 & 45 & 56 \\
\hline 18 & 65 & 74 \\
\hline 19 & 72 & 78 \\
\hline 20 & 45 & 53 \\
\hline 21 & 42 & 51 \\
\hline 22 & 52 & 60 \\
\hline 23 & 42 & 65 \\
\hline
\end{tabular}

Dengan menggunakan uji $\mathrm{t}$ dua sampel atau uji $\mathrm{t}$ test Paired dengan menggunakan SPSS diperoleh data sebagai berikut.

Tabel 2 Paired Samples Statistics

\begin{tabular}{|c|c|c|c|c|c|}
\hline & & Mean & $\mathrm{N}$ & Std. Deviation & $\begin{array}{l}\text { Std. Error } \\
\text { Mean }\end{array}$ \\
\hline \multirow[t]{2}{*}{ Pair 1} & $\begin{array}{l}\text { Nilai Sebelum Diberikan } \\
\text { Pelatihan }\end{array}$ & 53.74 & 23 & 13.356 & 2.785 \\
\hline & $\begin{array}{l}\text { Nilai Sesudah diberikan } \\
\text { Penilaian }\end{array}$ & 60.61 & 23 & 11.847 & 2.470 \\
\hline
\end{tabular}

Tabel 3 Paired Samples Correlations

\begin{tabular}{|ll|r|r|r|}
\hline & N & Correlation & Sig. \\
\hline Pair 1 & $\begin{array}{l}\text { Nilai Sebelum Diberikan } \\
\text { Pelatihan \& Nilai } \\
\text { Sesudah diberikan } \\
\text { Penilaian }\end{array}$ & 23 & .782 & .000 \\
\hline
\end{tabular}

Tabel 4 Paired Samples Test

\begin{tabular}{|c|c|c|c|c|c|c|c|c|c|}
\hline & & \multicolumn{5}{|c|}{ Pared Difarences } & \multirow[b]{3}{*}{$t$} & \multirow[b]{3}{*}{ di } & \multirow[b]{3}{*}{ Sig (2-taled) } \\
\hline & & \multirow[b]{2}{*}{ Wean } & \multirow[b]{2}{*}{ stid. Deviaton } & \multirow{2}{*}{$\begin{array}{l}\text { S1d. Error } \\
\text { Nean }\end{array}$} & \multicolumn{2}{|c|}{$\begin{array}{l}\text { 95\% Confidence interval of the } \\
\text { Deference }\end{array}$} & & & \\
\hline & & & & & Lower & Ubovt & & & \\
\hline Pair 1 & 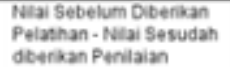 & .6 .870 & 8.444 & 1.761 & -10.521 & .3218 & -3902 & 22 & .001 \\
\hline
\end{tabular}




\subsection{Pembahasan}

Dari hasil perhitungan menggunakan SPSS pada Tabel 4 diperoleh nilai korelasi sebesar 0,782 dengan kategori mempunyai hubungan yang kuat antara niali sebelum dan sesudah diberikan pelatihan. Nilai probabilitas/ $\mathrm{p}$ value uji $\mathrm{T}$ Paired: Hasil $=$ 0,001. Artinya: ada perbedaan antara sebelum dan sesudah perlakuan. Sebab: Nilai p value > 0,05 (95\% kepercayaan). Sehingga bisa disimpulkan bahwa penyuluhan tentang pengerjaan soal matematika berhasil meningkatkan kemampuan.

Hal-hal yang perlu ditingkatkan dalam belajar dari sisi siswa yaitu:

1). Meningkatkan kontiunitas belajar

2). Memiliki soal-soal yang variatif.

\section{SIMPULAN}

Kesimpulan dari proses pengabdian kepada masyarakat yaitu:

1). Terjadi peningkatan kemampuan penyelesaian soal matematika sesudah diberikan tritment penyuluhan penyelesaian soal.

2). Hal yang perlu ditingkatkan sebagai dorongan kesadaran yaitu luangkan waktu secara terus menerus untuk berlatih dan belajar sehingga akan menimbulkan kesadaran yang baik, memiliki soal-soal yang bervariatif.

Saran dari pelaksanaan pengabdian kepada masyarakat yaitu:

1). Untuk yayasan CIMI dapat mencari soal-soal yang variatif dari web yang berintegritas serta mengumpulkan buku soal-soal yang relevan.

2). Untuk siswa tingkatkan kontinuitas belajr sehingga akan menimbukan rasa suka terhadap matematika.

3). Untuk orang tua siswa diharapakn bisa menemani saat belajar sehingga anak akan merasa lebih nyaman dalam belajar.

\section{DAFTAR PUSTAKA}

Khairudin, K., \& Niniwati, N. (2020). Pelatihan Menganalisis dan Menyelesaikan Soal Matematika Berorientasi Higher Order Thingking Skills (HOTS) bagi Guru SMA Kabupaten Padang Pariaman. Jurnal Pengabdian Pada Masyarakat, 5(2), 443-450.

Arikunto, Suharsimi. (2012). Dasar-Dasar Evaluasi Pendidikan. Bumi Aksara: Jakarta. 